\title{
SOME ECONOMIC ASPECTS OF IMMIGRATION INTO THE UNITED STATES
}

\author{
Joseph J. SPENGLER*
}

Pleasure or businesse, so, our Soules admit

For their first mover, and are whirld by it.

Hence is't, that I am carryed towards the West.

John Donne

This paper has to do with the economic aspects of American immigrationamong them, the capacity of the American economy to absorb immigrants and the probable response of the American economy to variations in the volume of immigration. Accordingly, both a historical and an analytical approach are employed. Part I is given to an historical résumé of the economic dimensions of American immigration. A summary account of the actual effects of immigration upon the American economy is presented in part II. Parts III and IV are devoted to an outline of the implications of economic-demographic theory for the subject under consideration. In part $\mathrm{V}$, conclusions for policy based upon the preceding historical and analytical sections are indicated.

\section{I}

\section{Historical Background}

The movement of population from Europe to the lands across the sea during the past century and a half is divisible into two parts; a redistribution of population within the Atlantic economy, and a passage of people from Europe to countries

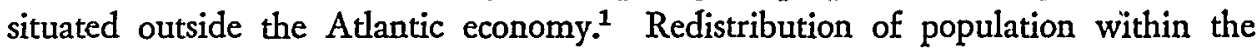
Atlantic economy accounted for the major part of this transoceanic movement, and emigration to the United States dominated this redistributive process. Between I800 and I950, about 67 million emigrants crossed the ocean, of whom "approximately 60 million were Europeans, and, of these, some 40 million came to the United States." While many of these migrants returned to Europe, somewhat in excess of

*A.B. 1926, M.A. 1929, Ph.D. 1930, Ohio State University. James B. Duke Professor of Economics, and Director of Graduate Studies in Economics, Duke University. Consultant on Population to United Nations, 1950-5i. Author, France Faces Depopulation (1938); French Predecessons op Maltrus (r942). Contributor to scholarly periodicals on demographic and economic subjects.

${ }^{1}$ See Brinley Thomas, Migration and Economic Growth cc. I, 14 (1954).

2 W. S. and E. S. Woytinsky, World Population and Production 72 (1953). Some 45 million persons emigrated from Europe to North America between 1600 and 1950, of whom some 25 million remained; approximately 20 million, of whom close to I8 million remained, went to Middle and South America; over 5 million went to Oceania and Africa. Negro slaves imported into the Americas numbered nearly 15 million. See $i d$. at 69,72 . Asiatic migration has been much less intercontinental than has European. Only about 3 million emigrants left Asia in 1800-r950. Of the 30 million cmigrants who left India and Pakistan in $1834-1937$, about 24 million returned, while of the approximately 5 million persons of Indian descent living outside India around r940, about four-fifths resided in Burma, 
70 per cent remained, with the ratio of net to gross immigration declining from close to roo per cent in the I820's to around 65 per cent in $1900-30 .^{3}$

TABLE I

Immigration and Population Growth, the United States, i850-1950 (in millions)

\begin{tabular}{|c|c|c|c|c|c|}
\hline \multirow[b]{2}{*}{$\begin{array}{l}\text { Census } \\
\text { Year }\end{array}$} & \multirow{2}{*}{$\begin{array}{c}\text { Population } \\
\text { (reported } \\
\text { by Census) }\end{array}$} & \multicolumn{2}{|c|}{$\begin{array}{c}\text { Foreign-BorN WhITE } \\
\text { POPULATION }\end{array}$} & \multirow{2}{*}{$\begin{array}{c}\text { Gross } \\
\text { Immigration } \\
\text { in Preceding } \\
\text { Decade }\end{array}$} & \multirow{2}{*}{$\begin{array}{c}\text { Net } \\
\text { Immigration } \\
\text { in Preceding } \\
\text { Decade }\end{array}$} \\
\hline & & Total & $\begin{array}{l}\text { Increase in Pre- } \\
\text { ceding Decade }\end{array}$ & & \\
\hline $\begin{array}{l}1850 \ldots \ldots \ldots \\
1860 \ldots \ldots \ldots \ldots \\
1870 \ldots \ldots \ldots \\
1880 \ldots \ldots \\
1890 \ldots \ldots \ldots \\
1900 \ldots \ldots \ldots \\
1910 \ldots \ldots \\
1920 \ldots \ldots \ldots \\
1930 \ldots \ldots \ldots \\
1940 \ldots \ldots \ldots \ldots \\
1950 \ldots \ldots \ldots\end{array}$ & $\begin{array}{r}23.2 \\
31.4 \\
39.8 \\
50.2 \\
62.9 \\
76.0 \\
92.0 \\
105.7 \\
122.8 \\
131.7 \\
150.7\end{array}$ & $\begin{array}{r}2.2 \\
4.1 \\
5.5 \\
6.6 \\
9.1 \\
10.2 \\
13.3 \\
13.7 \\
14.0 \\
11.4 \\
10.2\end{array}$ & $\begin{array}{r}1.9 \\
1.4 \\
1.1 \\
2.5 \\
1.1 \\
3.1 \\
0.4 \\
0.3 \\
-2.6 \\
-1.2\end{array}$ & $\begin{array}{l}1.7 \\
2.6 \\
2.3 \\
2.8 \\
5.2 \\
3.7 \\
8.8 \\
5.7 \\
4.1 \\
0.5 \\
1.0\end{array}$ & $\begin{array}{l}1.42 \\
2.56 \\
2.07 \\
2.58 \\
4.96 \\
3.69 \\
6.24 \\
2.23 \\
3.34 \\
.07^{*} \\
.88^{*}\end{array}$ \\
\hline
\end{tabular}

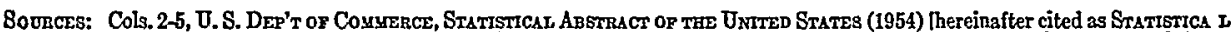

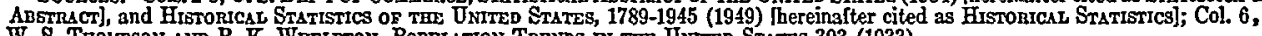
W. \&. Thoifson and P. K. WhelptoN, Poptlation Trends in the UntTed States 303 (1933).

*Based on STATISTICA ABETrAGT, sugra.

Figures presented in Table I suggest the order of magnitude of post-r 850 immigration into the United States, by decade, and the ostensible ${ }^{4}$ contribution of immigration to population growth. In the period $1800-40$, about 800,000 immigrants came to the United States, of whom about 750,000 remained. Thereafter, and until the I930's, gross immigration usually exceeded 200,000 per year and on six occasions

Malaya, and Ceylon. Of the approximately 8.5 million Chinese living outside China around i940, only $300-400$ thousand lived outside of Asia. Of the approximately 3.5 million Japanese living outside Japan proper in 1940, only about one-fifth were situated outside Asia. Nearly all the Koreans emigrating from Korea remained in Asia. See J. IsaAc, Economics of Migration 59-67 (I947); Kingsiey Divis, The Poptlation of India and Paxistan c. I3 (195x); United Nations, International Migrations in the Far East During Recent Times, I Populstion Bulx. 13 (1951), 2 id. at 27 (1952).

${ }^{3}$ Sec 2 Walter F. Willcox, Internationar Migrations 89 (I93I). A recent estimate suggests that Willcox underestimated the ratio of net to gross, and that census enumerations somewhat understate the number of foreign-born. See S. KuzNets AND E. Rubin, ImMigration and tHe Foreign Born 14-30, 87-94 (1954). Cf. cols. 5 and 6 in Table $I$. The fall in the ratio of net to gross immigration is attributed in considerable measure to the fact that the number of departures is a function of an increasingly large foreign-born population, whereas the number of arrivals is a function of a less rapidly expanding source of migrants.

- Benjamin Franklin, F. A. Walker, and others have contended that when immigrants move into an already occupied country, their coming causes the fertility of the population resident in that country to fall and stimulates some members of this population to emigrate. These writers have concluded, therefore, that, in the long run, a net influx $m$ of immigrants will increase the population of a given country of immigration by less than $m$ if it increases that population at all. Some admit, of course, that the rate at which this population increases will rise at first in consequence of the influx of immigrants, only to decline subsequently. It is not possible to subject the Walker thesis to careful empirical tests. It is arguable, however, that an influx of immigrants may increase, decrease, or not affect at all the longer-run rate of growth of a resident population, with the actual outcome depending on what conditions hold. Sce ThOMpson AND Whelpton, op. cit. supra Table I, at 302-II; also Spengler, On the Effects Produced in Immigrant-Receiving Countries by Pre-1939 Immigration, in INTERnatronal. MigraTION (Brinley Thomas ed. to be published 1956). 
exceeded I,000,000 per year, while the average annual volume of net immigration ranged between $x_{40}$ and 620 thousand. In consequence, the foreign-born white population long increased somewhat more rapidly than the native population, the ratio of foreign-born to the total population rising from .097 in $185^{\circ}$ to a peak of .r45 in I9ro. Immigration contributed significantly to American population growth, net immigration approximating 8 per cent of the total population in $183^{8-6 r}$ and, thereafter, gradually declining to 2 per cent in r918-32.5 Net immigration accounted for about $3^{\mathrm{r}}$ per cent of the increase in population taking place in the period I840-r9ro. By I920, according to one estimate, of the 94.8 million whites living in the United States, 53.5 million represented immigrant stock, with immigrants, children of immigrants, and grandchildren and later generations of immigrants, respectively, numbering 13.7 , r9.2, and 20.6 millions. ${ }^{\circ}$ Nonetheless, despite the continuation of a high incremental rate of immigration, the rate of growth of the American population began to decline after the Civil War; it fell from the level of 33-36 per cent per decade obtaining in I790-r860 to levels of approximately 26 per cent per decade in I860-90, 2 I per cent in I890-I9Io, and, thereafter, except for the depression decade I930-39, I5 per cent.

The decline in gross immigration which set in after it had reached maximum levels in I900-I4 was not attributable entirely to a decline in emigration from Europe. The number of European emigrants declined, it is true, from Ir.3 million in Igor-ro to 7.6 and 6.6 millions in the two decades that followed, and then slumped to $\mathrm{r} .9$ million in I93 I-40 and some $\mathrm{I} .6$ million in I94I-50. This decline, occasioned initially by World War I, was attributable in part to the introduction of quota and other restrictions on immigration, to the recurrence of unfavorable business conditions, and to political circumstances which culminated in World War II and the post-war spread of Communist governments. In the absence of these adverse conditions, emigration from Europe would probably have continued in considerable volume, despite the decline in the rate of natural increase in northern and western Europe. For around I930, there still existed in southern and eastern Europe a "surplus" agricultural population of perhaps 37 million, and around 1940 , it appeared likely that the population of these parts of Europe would increase another 26 million by $x 970 .^{7}$ Even so, the relative number of European emigrants going to the United States would have declined somewhat, though not nearly so much as it did after the introduction of restrictive measures in the United States, for the economies of Canada, Australia, Brazil, and Argentina had developed sufficiently by the late nipeteenth century to attract immigrants in volume. As it was, the percentage immigrants into the United States constituted of all intercontinental migrants declined from about 70 per cent in I821-90, through about 60 per cent in r890-rgro and 50

\footnotetext{
'See KUzNeTs AND RuBin, op. cit. supra note 3, at 2, 2I-26.

'See Spengler, The Merits and Demerits of the National Origins Provisions for Selecting Immigrants, Io Sw. Pol. \& Soc. Scr. Q. 155 (I929). See also Thompson and Whelpton, op. cit. supra Table I, c. 3 .

${ }^{7}$ See W. E. Moore, Economic Demography of Eastern and Southern Europe 56-76 (1945).
} 
per cent in IgII-30, to 20 per cent in I93I-40; it may have amounted to as much as 46 per cent in I94I-50. Most of the European immigrants who did not go to the United States went to British dominions and colonies (principally Australia, New Zealand, Canada, Africa) or to Latin America (principally Brazil and Argentina). ${ }^{8}$

In as much as migrants are prompted to move by the prospect of improving their situations, and since they usually interpret prospects in economic terms, the movement of immigrants into a country is dominated by the conditions surrounding the demand for labor in that country, while the movement of emigrants out of a country is usually dominated by the rate at which the labor force is growing, together with the circumstances governing job opportunities. The conditions surrounding the demand for labor in the United States were attractive in terms of European standards, it will be indicated later, except in periods of transient unemployment. The internal conditions by which the disposition of Europeans to emigrate was chiefly affected were four in number: (I) the movement of relative and absolute natural increase; (2) the movement of surplus labor out of agricultural areas; (3) the progress of industrialization and urbanization; and (4) variations in the rate at which capital was formed in the nonagricultural sector.

(I) Absolute natural increase expanded little in Europe between I820 and I9r4, but it fluctuated considerably, producing fluctuations in the growth of the labor force fifteen or more years later, and in the volume of emigration about twenty-five years later. Moreover, after I880, the rate of natural increase of the agricultural countries rose relatively to that of the industrial countries, with the result that population pressure in the agricultural countries came to exceed even more than formerly that found in the industrial countries." (2) "Throughout the period I820I940, an excess of labor was to be found in many rural areas, ready to move in response to the prospect of a slight improvement or under the impact of adversity (e.g., Irish crop failure; depression of European agricultural prices by agricultural expansion abroad); it had to find employment in domestic industry or in lands of immigration. (3) Industrialization and urbanization progressed, spreading eastward and southward, usually very slowly, but sometimes at a rate sufficient to increase employment opportunities for those seeking work in the nonagricultural sector and to produce changes in the social structure. (4) While capital was increasingly to be had in northern and western Europe, not a great deal was formed or otherwise obtainable in southern and eastern Europe, even though the absolute increment in population was growing; whence, additions to the labor force in these

\footnotetext{
${ }^{8}$ See Wortinsky, op. cit. supra note 2, at 76-80. Quota immigrants from Europe aggregated 624 thousand in 1940-50; all immigrants from Europe numbered 746 thousand in $1941-50$. See id. at 8I, 83. For emigrants from Europe, see $i d$. at 75 . Cf. S. N. Prokopovich, L'industrialisation Des Pays Agricoles et la Structure de l'Économie Mondiale après IA Guerre 126-39 (1946). Because of the pull of the American economy, Canada lost more migrants to the United States than she attracted from abroad in I86I-Igor, but thereafter, usually experienced net immigration. See Nathan Keyfitz, The Growth of Canadian Population, Population Studies 62 (1950).

${ }^{\circ}$ See Thomas, op. cit. supra note $\mathrm{I}$, at 80 81, II6-18, 156-58, 218-19, 313-14; Proropovich, op. cit. supra note 8, at $154-56,308-09$; I. Svennilson, Growth and Stagnation in the European Economy c. 4 (1954).
} 
parts were under pressure to emigrate. With (3) and (4) was associated a diminution in the physical and the monetary costs of immigration..$^{10}$

The conditions described varied from country to country. They changed, with the eastward and southward spread of the forces of economic development, in such manner that, as the disposition to emigrate diminished in the lands facing the North Atlantic, it increased in the lands lying to the East and the South. Prior to 1850, northwestern Europe was the source of somewhat more than four-fifths of intercontinental emigration of European origin. As late as $1871-80$, it furnished 65.4 per cent, and central Europe 23.4 per cent, of this emigration. After 1880 , and especially after 1890 , the relative number of emigrants from Latin and East-European countries increased, rising from one-fourth of the total in $188 \mathrm{I}-90$ to about one-half in 189I-1930. The fraction contributed by the British Isles, 76.1 per cent in 1821-40, fell to 53.2 per cent in $\mathrm{r} 86 \mathrm{I}-80,25.6$ per cent in $\mathrm{I} 88 \mathrm{I}-\mathrm{I} 920$, and $\mathrm{I} 3$ per cent in $193 \mathrm{I}-38$. The proportion originating in the industrial countries of Europe, comprising nearly all emigrants before 1840 , fell to $8 \mathrm{r}$ per cent by $186 \mathrm{r}-80$, and to about 27 per cent by IgOI-20; it rose to 43 per cent in rg2I- 38 as a result of the establishment of selective quotas in countries of immigration. These changes are reflected in the fact that by 1930, only 39 per cent of the foreign-born population was from Germany and northwestern Europe, whereas, in $185^{\circ}$ and 1890 , the corresponding percentages were 90 and 77. In general, emigrants tended to come from economies, which, being agricultural and relatively unprogressive, could not absorb their growing labor force on terms comparatively satisfactory to workers, rather than from progressive economies which were providing improved industrial opportunities for those entering the nonagricultural labor force. ${ }^{11}$

The southward and the eastward shifts of the sources of immigration were accompanied by changes in the composition of the immigrant stream and in the nature of its impact on the American economy. An increasingly large proportion of the immigrants came from relatively underdeveloped agricultural countries, with the result that the occupational composition of the immigrants came to be increasingly inferior to that of an American population which was living in one of the industrially most progressive parts of the world. Many of the "new" immigrants from predominantly agricultural southern and eastern Europe were comparatively illiterate and lacking in occupational and industrial skills. Moreover, many of those

\footnotetext{
${ }^{10}$ See Thomas, op. cit. stipra note $r$, cc. $3,10,12$, and 13 ; D. S. Thomas, Social and Economo Aspects of Swedish Population Movements cc. 2-3 (i941); Prokopovich, op. cit. stipra note 8, c. 4; D. Kirk, Europe's Population in the Interwar Years cc. 4-6, 8 (1946); C. Clark, Conditions of Economic Progress cc. 9, il (2d ed. I95I); H. Feis, Europe, The Worto's Banker, i87o-rgia passim (r930); SVennilson, op. cit. stipra note 9, c. 4 .

11 See Woyrinskx, op. cit. supra note 2, at 75-76; Prokopovich, op. cit. supra note 8, at 126-27. The increase in the relative number of migrants of Latin origin accounted in part for the increase in the relative number of European emigrants who went to Latin America. While emigration from Europe rose from I per 1000 inhabitants in $1846-50$ to 2.5 in $1901-05$ and 4.3 in 1913 , it attaincd higher levels in particular countries, e.g., 8.4 in the United Kingdom in $1853-55$ and $x 1.6$ in Italy in 1906-ro. Net emigration reached 7 per 1000 in Sweden in 1886-90, 6.3 in Italy and 5.5 in Finland in I90I-05. See IsaAc, op. cit. supra note 2, at 64-65.
} 
who possessed craft and occupational skills, finding them not to be ones in great demand, entered new occupations. It became possible to make effective use of this vast influx of unskilled workers because, in the late nineteenth century, American industry became technologically and economically adapted to the utilization of many workers possessing little or no skill, with the result that craft and handicraft skills were diluted and reduced in relative significance. ${ }^{12}$

The absorption of so large and sustained a volume of immigrants into the American economy was greatly assisted, as was that of domestic population growth, by the availability of land for settlement and by the high rate at which capital was formed. Between I850 and 1935, farm land increased from 294 to $\mathrm{r}, 055$ million acres, and crop land from II3 to 416 million acres, at a rate less rapid than that at which the number of farms or the total population grew, but more rapid than that at which the farm population grew. Investment in agricultural plant progressed about 3 per cent per year in $1870-1920$, thereafter to increase only .26 per cent per year; but yields per acre, after having risen relatively little for three to five decades, increased sharply after the middle $193^{\circ}{ }^{\prime} .^{13}$ Reproductive tangible wealth grew much more rapidly than population, with real wealth per head increasing 2.5 per cent per year in 1850-1900, when population was growing 2.4 per cent per year, and I.3 per cent per year in I900-I950, when population was advancing I.4 per cent per year. ${ }^{14}$ The rapidity with which real wealth per head grew is attributable to the high levels of productivity early achieved in American industry, ${ }^{15}$ to the maintenance of a high rate of capital formation, to the fact that the United States was spared the cost of producing a considerable fraction of its population, and to the influx of foreign capital which helped to equip the immigrant population. ${ }^{16}$

The economic absorption, though not necessarily the assimilation, of immigrants

${ }^{12}$ E.g., see Thomas, op. cit. supra note $\mathrm{I}$, at $60-63,148-5 \mathrm{I}, \mathrm{165-74}, 268-72$; H. D. ANDERson AND P. E. Davidson, Occupational Trends in the United States 53-57, 166-67, 572-74 (1940); also Spengler, supra note 4 .

${ }^{13}$ Historical Statistics, op. cit. stipta Table I, at 29, 95, 121; J. F. Dewhurst, America's Needs and Resources 793-99 (i955); A. S. Tostlebe, The Growth of Phystcal Capital in Agriculture, I870-I930 passim (I954).

" See S. KuzNets aNd R. W. Goldsmith, Income and Wealth of the United States 269 (I952).

${ }^{10}$ See Rothbarth, Causes of the Superior Efficiency of U.S.A. Industry as Compared With British Industry, 46 EcoN. J. 383 (x946); Frankel, Anglo-American Productivity Differences: Their Magnitude and Some Causes, 45 AM. Econ. Rev. 94 (r955).

${ }^{10}$ Net capital formation approximated 13 per cent of net national product in 1869 -r 928 , according to KUZNETS AND GoLDSMITH, op. cit. stipra note 14, at 155 . Even so, the rate at which capital was formed was much below the level at which it might have been formed. See F. C. Mirls, Productivity AND Economirc Progress I4 (I952). If, as of 1930, a value of 3-10 thousand dollars is placed on each of the 27.5 million net immigrants into the United States in $1821-1930$, the product, $\$ 82-275$ billion, represents a large fraction of the country's accumulated wealth, $\$ 362$ billion, in 1929. See de Vita, Der kapitalisierte Wert der $1820-1930$ in die Vereinigten Staaten von America Eingewanderten, 52 WELTWIRTSCHAFTZICHES ARChIV 3I (1940); KUZNETS AND GoldSMITH, op. cit. supra note 14, at I98. Even if a lower value is set upon each immigrant, on the ground that the alternative use value of the resources incorporated in personal capital would have been less, the capital value of resources saved would still be large. Between I 880 and I9ro, net foreign investment exceeded $\$ 800$ per foreign worker added to the labor force. This amount exceeded the value of equipment per worker prior to the early I900's, but was much less than the amount of reproducible capital per member of the labor force. See id. at $78,155,197,204-05,300-07,323$. 
was facilitated by the fact that most of them settled in a small number of states and largely within towns and cities in those states. In $1850,83.6$ per cent of the foreign-born whites lived in the New England, Middle Atlantic, and East North Central States; the corresponding percentage was 72.x, 77.3, and 69.7 in 1900, I930, and 1950. By 1890 , I7 per cent were situated in the West North Central States; but by 1950 , this percentage had declined to 8.3 , while that reported for the Pacific Coast had risen to 1 r..$^{17}$ The geographic concentration of immigrant settlement was accompanied also by industrial concentration, in part because cultural and other disadvantages under which immigrants often labored reduced their access to some employments. Among the industries into which they crowded were mining, quarrying, clothing, textiles, woolen and worsted mills, bakeries, meat packing, car and railroad shops, silk and carpet mills, brass and rolling mills and blast furnaces, breweries, tanneries, hat factories, lime, cement, and gypsum factories, marble and stone yards, rubber factories, piano and organ factories, construction and maintenance. ${ }^{18}$ Concentration of immigrants in cities where they and their children had access to educational opportunities facilitated the occupational and industrial progress of persons of immigrant stock..$^{19}$

II

\section{IMMigRATION AND tHE AMERICAN Economy}

Immigration into the United States produced a diversity of effects which, in turn, modified the magnitude, the structure, and the behavior of the American economy. Immigration augmented the rate of growth of the net national product, made possible a better combination of productive agents, and until around the turn of the century, probably accelerated the rate at which product per capita increased. Immigration augmented the rate of growth of the net national product, made scribed in part I, in part because the aboriginal population was sparse, in part because the external economic relations of the American economy were good, and in part because the American population, though of heterogeneous origin, shared a developing culture that was suited to give it sufficient socio-economic unity while reinforcing values conducive to material productivity.

Among the specific effects produced by immigration, the following may be noted:

(I) A disproportionately large fraction of the immigrants were of working age; thus, whereas, in I870-I910, immigration increased the population by about 15 per cent, it swelled the labor force by about 20 per cent.

(2) During the first three-quarters or so of the nineteenth century, many of the immigrants brought with them scarce but useful occupational skills and superior

\footnotetext{
${ }^{17}$ See Thompson and Whelpton, op. cit. supra Table I, at 247; Statistical Abstract, op. cit. supra Table I.

${ }^{18}$ See Eckler and Zlotnick, Immigration and the Labor Force, 261 ANNALs 92 (1949); Oscar Handin, Boston's IMMIGRANTs, 1790-I865 passim (1941).

${ }^{19}$ See Thoms, op. cit. supra note $\mathrm{I}$, c. 9.
} 
industrial methods, together with some relaxation of the customs and horizons by which their efforts had been bound in the countries of provenience. ${ }^{20}$

(3) The mingling of peoples of diverse cultural backgrounds may have given rise to cultural as well as to biological heterosis, thereby augmenting productive power. ${ }^{21}$

(4) The manner in which one ethnic group has succeeded another as a dominant element in the stream of immigration, together with the resulting intensification of social and economic capillarity (see part III), helped to foster the pursuit of material success and to generate that spirit of comparatively unrestricted economic competition which appears to distinguish the American from most other economies. ${ }^{22}$

(5) Immigration fostered homogeneity of tastes and, therewith, the development of a large market for the standardized products of highly mechanized industries; for, no one ethnic group being able to impose its tastes on other groups, each and all adopted the tastes that they found in America and readily acquiesced in the changes technologically minded producers found it economical to make in their products. $^{23}$

(6) The comparative docility of immigrant workers operated, in and after the last quarter of the nineteenth century, if not earlier, to facilitate the introduction of efficient, highly mechanized, mass-production methods.

(7) Heavy and continuing immigration of relatively unskilled workers prevented the real earnings of unskilled labor and of much manufacturing labor of somewhat more skill from rising significantly, when they rose at all, in the period I8go-rgr4, even though output per man-hour was rising perhaps as much as 44 per cent; and it may account for the fact that real wages rose relatively less in the United States in I860-rgr3 than in the United Kingdom and some West-European countries. ${ }^{24}$

(8) Presumably, immigration, by depressing the ratio of wages received to marginal product, somewhat augmented the "surplus" whence most capital comes. ${ }^{25}$

${ }^{20}$ See R. T. Berthoff, British IMmigrants in INDUSTRIAL AMERICA I790-1850 passim (I953); M. L. Hansen, The Inmigrant in American History passim (i940); Herbert Heaton, The Industrial Immigrane in the United States, 1783-1912, 95 Proc. AM. Phr. Soc'y 519 (195I); Crark, op. cit. stupra note 10, at 206-07, 245. "The immigrants developed the physical riches of America: and, in return, the new hope, freedom, and changefulness of their lives developed in them germs of high spirit and initiative," germs latent in most people, but especially in those "who seek new lands." AlfreD Marshali, Industry and Trade I43 (1927).

${ }^{21}$ See Snell, Hybrids and History, The Role of Race and Ethnic Crossing in Individual and National Achievements, 26 Q. REv. Brou. 33I (195T).

22 The American culture is shot through with ingredients making for productivity. See T. Parsons, Soctal Systek c. 5 (I95I); and of. Marshal, op. cit. supra note 20, at I49-50.

${ }^{23}$ The wide separation of the producer from the consumer, as Marshall observed, also served "to suppress those methods of production which depend for their strength largely upon the adaptation of products to the special requirements or tastes of the purchaser." MARsHaLl, op. cit. supra note 20, at I $46-47$.

34 See Paul H. Douglas, Reat Wages in the UNTted States, i 890-r926 passim (i930); W. Coombs, The Wages of Unskilied Labor in the Manufacturing Industries in the United States, 1890-1924, c. 5 (1926); W. S. Thompson, Population: A Study in Malthusianism 39 et seq. (rgr5); KuzNETS AND Goldsmir, op. cit. supra note 14 , at $7 \mathrm{r}$; Brown and Hopkins, The Course of Wage-Rates in Five Countries, 1860-1913, 2 OXford Econ. PApers 236 (1950).

${ }^{25}$ Both gross and net capital formation were higher between 1884 and 1904 than before or after this time. KuZNETS AND GoldSMitTr, op. cit.. supra note $\mathrm{x}_{4}$, at 155 . 
(9) Immigration certainly affected and may have retarded the progress of trade unionism in the United States, thereby insuring its own continuation since organized labor favored the restriction of immigration. ${ }^{26}$

(Io) The international mobility of population made possible largely by free migration to America before World War I, together with such economic fluidity as it produced, helped make workable the system of fixed exchange rates in effect in many countries before $1913 .{ }^{27}$

(II) As has been noted, the availability of capital was affected by the volume of immigration. Before 1914, the influx of immigrants, and sometimes the mere prospect of such an influx, stimulated inflows of capital from Europe, then the world's banker. Immigrants brought some capital with them and, as remarked above, by their coming, spared America the cost of producing some 25 million people. Furthermore, immigration, in so far as it increased the profitability of American industry, stimulated domestic capital formation. On the whole, therefore, immigration may be said to have produced side effects which made for capital formation and, thus, counterbalanced much of the increase in capital requirements occasioned by immigration and the disposition of immigrants to make remittances. It did not, presumably, generate much, if any, inflationary financing of capital formation, or produce much, if any, unemployment. That immigration did, however, absorb a portion of the annual supply of capital is suggested by the increase that took place in the supply of American funds available for foreign investment after quota restrictions had reduced the inflow of immigrants. ${ }^{28}$

(x2) Immigration stimulated the growth of net national product per head in at least two ways in addition to those discussed above. (a) So long as the Atlantic economy remained subject to increasing return, the movement of people to undersettled parts of this economy, especially to the United States, stimulated the growth of these parts, and their increased import demands fostered economic development in the lands of immigrant provenience, with the result that the consequently increased import demands of these countries, in turn, stimulated further growth in the immigrant-receiving countries. ${ }^{2 \theta}$ (b) Because of the magnitude of immigration into the United States before IgI4 and its acceleration of the growth of the American population and its economy, this economy was continually outstripping its stock of capital, with the result that investment was less risky than in other countries, even though capital was being formed and introduced at a higher rate than elsewhere. At the same time, labor (or at least many forms of labor) was usually in short

${ }^{26}$ See H. A. Milis and R. E. Montgomery, Organized Labor 14-15, 48-49, 88-90, 124, $154-55$ (1945); S. Perlman, A History of Trade Unionism in the United States 84 et seq., I79-221 (I923); Thomsas, op. cit. supra note $I$, at 204-05. The role of immigration in a trade union movement depends, of course, upon the background and industrial and union experience of the immigrant workcrs. Many of the immigrants to America had had no such experience. In Australia, by contrast, a powerful trade union movement was established early.

${ }^{27}$ See A. P. LeRner, Economics OF EMPLOYMENT 358 et seq. (r951).

${ }^{28}$ Sce Thomas, op. cit. supra note $\mathrm{I}$, at 199-201. In the 1920's, capital was formed at a lower relative rate than earlier. See KuZNETS AND GoLDSMmT, op. cit. stupra note 14, at 155 .

${ }^{20}$ See Royal Commission on Population, Report of the Economics Committee, in 3 Papens 5 (1950). 
supply. There was no substantial opposition, therefore, to the increasing mechanization of American industry and the continual introduction of ever more effective labor-saving machinery. Furthermore, because of the high rate at which the stock of capital was being increased, a considerable fraction of this stock was made up, at all times, of relatively new and highly productive forms. ${ }^{30}$ In short, immigration kept the growth process triggered off while it was bringing into being ever more efficient ways of combining productive agents. It stimulated both capital formation and technological change, the two forces which have been responsible for the major part of the increase in output per head experienced in the past $15^{\circ}$ years.

Migratory movements are subject to both short-period and long-period fluctuations, which have their origin both in countries of provenience and in countries of destination; and many of the effects consequent upon immigration reflect these variations. In the past, arrivals, departures, and net arrivals have moved together, but net arrivals have varied most; for while arrivals fluctuated with business cycles, departures tended to contract during expansions and to expand during contractions, perhaps because they were less subject than arrivals to legal controls. ${ }^{31}$ Waves of arrivals had their origin in the European births cycle and in the impact of innovations in Europe, only to be succeeded by "minor secular upswings in the rate of economic growth."32 Long "swings in net immigration tended to follow those in gross national product per worker, and to precede those" in nonfarm residential construction, which, together with capital expenditures by railroads, made up what Kuznets calls "population-sensitive" capital. Swings in this sector of capital formation were positively correlated with swings in population growth and negatively correlated with swings in other sectors of capital formation, probably because enough savings were not forthcoming in the United States to meet fully the demands for both categories of capital..$^{33}$ Thomas found that, as a rule, immigration preceded building activity in the United States, which was inversely associated with building activity in Great Britain, the other main member of the Atlantic economy and a major source of the building-stimulating migrants. He reports also that whereas in $1844-63$ immigration preceded the movement of railroad construction, merchandise imports, and fixed-capital investment, it lagged after rail construction from $r 869$ on, and after the output of coal and pig iron from 1899 on. He infers that immigration was under the dominance of European "push" factors before I870, only to pass under that of American "pull" factors, among them, the pace of investment, after $1870{ }^{34}$ While immigration may have prolonged boom periods by continuing to make labor available on satisfactory terms and may, therefore, have

${ }^{\text {so }}$ J. M. Keynes and E. A. G. Robinson have drawn attention to the importance of point (b). Cf. KuzNETS AND Goldsmith, op. cit. supra note I4, at $86-88$, for evidence of the buoyancy with which American entrepreneurs assumed risks.

${ }^{31}$ See KuzNeTs and Rubin, op. cit. supra note 14, at 36-37.

32 Tromas, op. cit. supre note $\mathrm{I}$, at 174 .

${ }^{33}$ Kuznets and Rubin, op. cit. supra note 3, at 27-34. The connections between swings in population and capical are treated by Kuznets in a forthcoming study.

${ }^{34}$ See Thomas, op. cit. stupra note $\mathrm{I}, \mathrm{cc} .7$, xo, and $\mathrm{xI}$. 
intensified the severity of the depressions that followed, it is not evident that the ratio of years of prosperity to years of depression was significantly affected. ${ }^{35}$

In the light of what has been said in parts I and II, a strong case can be made for the proposition that until the close of the nineteenth century and possibly until the outbreak of World War I, immigration contributed directly and indirectly to the complex of synergistic forces that were making for the growth of both net national product and the amount produced per head. It is doubtful, however, whether this proposition remained valid after World War I. In the two parts that follow, grounds for this doubt are set forth.

\section{III}

\section{Substitutive, Complementary, and Aggregative Effects of Immigration; Social Capillarity ${ }^{36}$}

For purposes of analytical and expositive convenience, the economic effects produced by immigration into a country may be divided into two categories: (a) those which are substitutive, complementary, or (if there be such) neutral in character; and (b) those which are describable as aggregative in nature. Effects falling into category (a) are fairly easy to identify and impute, particularly if it is supposed that they are either substitutive or complementary. Effects belonging under (b) are not so easy always to identify, and they usually are very difficult to impute, since they are also producible by agents other than immigration. We shall note later to what extent the two kinds of effects may be added algebraically, and in what measure they may be considered indicative of changes in "economic welfare."

Let us first consider substitutive and complementary effects. Suppose that migrants moving from country $A$ to country $B$ include a relatively large number of workers who fall into four occupational categories, $a_{1}, a_{2}, a_{3}$, and $a_{4}$, and that country $B$ has a very low propensity to import and export. In the event that $B^{\prime} s$ labor force embraces four analogous occupational categories of workers, $b_{1}, b_{2}, b_{3}$, and $b_{4}$, the immigrant workers will be substitutable for native workers in these categories. In consequence (abstracting from income or aggregative effects and proceeding on the assumption that the immigrant workers find employment in their occupational categories), the relative rates of remuneration received by native workers in these occupational categories will decline. Simultaneously, the relative rates of remuneration received by native workers in other occupational categories than these four will rise, in part because the increase in categories $b_{1}-b_{4}$, which are complementary to all or most of categories $b_{5}-b_{\mathrm{n}}$, elevates the schedule of demand for (and the value productivity of) workers in the latter group of categories. In general, therefore, the native labor force will at first experience both substitution and

${ }^{35}$ See H. Jerome, Migration and Business Cycles 242 (1926); W. C. Mitchell, Business Cycles 410 (1928).

${ }^{36}$ In this section, the writer has drawn heavily upon the argument presented in Spengler, supra note 4 . 
complementary effects from the immigrant workers, with the substitution effect being overriding in proportion as the relative number of workers enrolled in categories $b_{1}-b_{4}$ was large already prior to the arrival of the immigrants.

Given (other things being equal) a change in the earnings structure consequent upon an influx of immigrants, native workers may respond variously. Those enrolled in occupational categories $b_{1}-b_{4}$, having had their relative and (perhaps) their absolute earnings reduced by the competition of these immigrants, may remove to less peopled part of country $B$, or even emigrate abroad; or they may attempt to enter occupations $b_{5}-b_{\mathrm{n}}$, in which event, members of these occupations will experience substitutive as well as complementary effects; or, if denied these recourses, they may reduce their net reproduction rate, thereby probably diminishing the potential number of recruits available for occupations $b_{1}-b_{4}$ fifteen to twenty years later. In each instance, the savings rates of the affected persons will tend to be reduced. Native workers in occupations to which the activities of the immigrants are complementary will undergo a contrary set of reactions. They will be less inclined to migrate or emigrate, less inclined to change occupation, and disposed to increase both their net reproduction and their savings rates.

If it be assumed that country $B$ has a high propensity to import and export and that its economy is open, as was the American in the nineteenth century, the impact of immigration into $B$ may be largely cushioned. Suppose that individuals engaged in occupations $b_{1}-b_{4}$ produce largely for export markets, the priceelasticity of demand for $B$ 's contribution thereto being very high. Then (assuming a sufficiency of land and other complementary imputs, ) the accession of immigrant workers in categories $a_{1}-a_{4}$ will not greatly depress the relative levels of earnings characteristic of occupations $b_{1}-b_{4}$, since the product of these additional workers can be sold abroad at but slightly reduced prices. Under these circumstances, much of the burden of adjustment will fall upon individuals living abroad who are members of occupations $b_{1}-b_{4}$ and whose situation may temporarily have been improved by the removal of the migrants in question. At the same time, the net aggregate impact experienced by the labor force enrolled in occupations $b_{\mathbf{5}}-b_{\mathbf{n}}$ will not be great, since the returns from the sale abroad of the additional exports must, in effect, be expended abroad. In sum, when (complementary inputs being assumed available) immigrants enter export industries for whose products price-elasticity of demand is great, the effect of their coming is relatively widely diffused, the domestic economy is more easily accommodated to their coming, the wage structure is less affected, and conditions of full-employment-insuring, balanced growth are more speedily approximated.

Let us now consider the aggregative effect of the influx of immigrants into $B$. There will be an increase in the aggregate amount of income produced in $B$. In fact, if $B$ is still subject to increasing return, or if the advent of the immigrants sufficiently stimulates capital formation, the introduction of superior methods, and technological progress, and produces others of the salutary effects described in the 
preceding part, the income of $B$ will increase in greater proportion than the population of $B$ has increased as a result of immigration, and income per head will rise. Under these circumstances, the aggregative effect of immigration would probably swamp its adverse substitution effects after enough time had passed to permit adjustment. Initially, absolute income per worker would rise in many of the occupations to which the economic activities of the immigrant workers were complementary. This rise would be relatively widespread after the composition of $B^{\prime} s$ labor force had become sufficiently adjusted to the influx of immigrant workers. It is not likely, however, that absolute income per worker would rise in occupations $b_{1}-b_{4}$ unless the population of $B$ had been subject to increasing return and a sufficient number of native workers in these occupations had moved into occupations $b_{5}-b_{n}$. The relative level of remuneration obtaining in occupations $b_{1}-b_{4}$ would remain lower than it had been prior to the coming of the immigrants, unless a distribution of workers among occupations substantially similar to that obtaining before the influx of immigrants had been restored.

So long as a significant amount of immigration continues and the occupational composition of the immigrant stream differs from that of the native population, both substitution and complementary effects will be experienced from the foreignborn immigrants. Even if the inflow of immigrants ceases but the occupational composition of their descendants continues to differ from that of the descendants of the native population, elements in the latter will experience substitution or complementary effects of immigrant-stock origin. If, however, immigration ceases, and, in time, the descendants of the immigrants become distributed in the same manner as the natives throughout the occupational structure, the natives will no longer be sensible as formerly of substitution or complementary effects from persons of immigrant stock. When this has become the situation, therefore, the economic status of the natives may be said to be better or worse than it would have been in the absence of immigration accordingly as the amount of equipment and wealth per head, together with the level of technology and related circumstances, is more or less advanced than it would have been in the absence of the influx of the immigrants. The long-run outcome, in short, turns on how powerful the aggregative effect was.

The advent of immigrants is likely to be accompanied, for a time, by an increase in social capillarity. Many, though not all, immigrants into the United States, particularly after 1880 , were under occupational, linguistic, personality, intellectual, and other handicaps, some transient and some not entirely removable. But these handicaps did not usually persist beyond the second or third generation. Accordingly, as these handicaps were dissipated, the positions occupied by persons of immigrant stock underwent change.

Let the occupational structure of a country be represented by four categories, $A, B, C$, and $D$, into which fall $10,20,30$, and 40 per cent, respectively, of the gainfully employed. Then, if there arrived to units of immigrants culturally and otherwise identical with the natives, the ro would tend to be distributed among 
categories $A-D$ in the same proportions as the native population, namely, $1,2,3$, and 4 units, respectively. If, however, the immigrants suffered under handicaps of the sort described above, more than 4 , say 8 , of the to units might have to enter category $D$, and, say, I each, into categories $C$ and $B$. Then, one of two outcomes would be possible. If the underlying determinants of occupational equilibrium were such as to maintain the proportions which prevailed prior to the arrival of the immigrants, there would be set in motion an upward movement of the native members of the occupational structure, eventuating, say, as follows: $A$, II natives; $B$, 2I natives and I immigrant; $C, 32$ natives and I immigrant; $D, 36$ natives and 8 immigrants. If, as is probable, equilibrium occupational composition changed, relative expansion would take place in the lower portions of the occupational pyramid, and there would eventuate a distribution such as the following: $A$, Io natives; $B, 20$ natives and $x$ immigrant; $C$, $3^{I}$ natives and I immigrant; $D, 39$ natives and $8 \mathrm{im}$ migrants.

The occupational composition of the children of immigrants would approximate more closely that of the natives than did the occupational composition of the immigrants themselves; and the occupational composition of the grandchildren of the immigrants would approximate that of the natives even more closely than did the occupational composition of the children of the immigrants. The rapidity with which the occupational composition of the immigrant stock approached that of the natives would depend upon how technologically, and, hence, occupationally, dynamic the country of immigration was, upon the extent and the rigidity of artificial and institutional barriers which tend to prevent interoccupational movement that would otherwise take place, and upon the degree to which these barriers impeded the interoccupational movement of persons of immigrant stock even more than that of natives. To illustrate: Earlier we put at .4 the probability that a native would be enrolled in occupational category $D$ and at .8 the corresponding probability for the immigrant; yet, all or nearly all of the spread between these two probabilities, being attributable to eliminatable differences between immigrants and natives, would disappear after one or several generations had passed. Then, the descendants of immigrants of a given period would no longer differ significantly from the descendants of natives of that same period.

It is said that immigration tends to make a population more fluid or mobile than it otherwise would be. This result is likely under two conditions: (a) when the occupational (or other) composition of the immigrants differs from that of the labor force of the country of immigration, with the result that a series of substitution effects is generated; and (b) when the coming of the immigrants produces or facilitates fundamental changes in the technological and related determinants of the occupational structure and sets both aggregative and substitutive effects in motion. For in either instance, the relative amount of movement from some to other occupational categories would increase and then remain at "abnormally" high levels until the labor force had become accommodated to the basic occupational structure and a 
model approximating that of Cairnes' and Taussig's relatively noncompeting groups had come into being. Initially, the upward mobility of the native population would increase in much greater degree than total mobility of the immigrant population. But, as the immigrants and their children became assimilated and, hence, freed of transient disabilities, their upward mobility would increase, and natives who no longer were capable of competing effectively with the upward-moving immigrant stock would be displaced downwards. When, however, the initial occupational composition of the immigrants is quite similar to that of the natives, the coming of the immigrants produces little change in the relative amount of interoccupational mobility, since little change is required to permit permanent occupational assimilation of the immigrants.

Substitution and social capillarity are readily illustrated: (a) It has already been indicated that relative earnings fell in industries and occupations into which immigrants entered in telatively large numbers. (b) Many immigrants changed their employments, and younger ones frequently improved their situations markedly. ${ }^{37}$ (c) After several generations had passed, persons of immigrant stock had virtually as free access to the upper reaches of the occupational pyramid as had had natives of some generations standing. ${ }^{38}$ (d) That immigrants and Negroes frequently are substitutively related to one another is suggested by the fact that few immigrants have settled in the South, that the migration of Negroes to industrial states did not become great until immigration had fallen off, and that interstate migration of foreign-born was sometimes inversely correlated with that of native whites and Negroes. As a rule, however, overriding influences which may be looked upon as aggregative in character have been dominant, with the result that Negroes, foreigners, and native whites have all alike been drawn from their points of origin to states, cities, and metropolitan centers where industrial opportunities abound for all.

Aggregative effects are easy to describe and sometimes to identify-a number of them have been described in part II-but they are seldom easy to assess in quantitative terms. It is rarely, if ever, possible to separate sharply income increases attributable to an influx of immigrants, particularly when that influx is continuous, from income increases imputable to increases in the stock of capital, to improvements in technology, or to similar agents. In the preceding part, however, we inferred that prior to I900, and possibly prior to $19 \mathrm{I} 4$, the aggregative effects of American immigration were sufficiently powerful to swamp most of its substitutive and complementary effects, and that, given a virtual discontinuance of immigration and time for all its effects to work out, the aggregative effects probably would have

${ }^{37}$ See Bloch, Occupations of Immigrants Before and After Coming to the United States 17 Punc'Ns am. Stat. Ass'n 750 (1920-21); P. E. Davidson and H. D. Anderson, Occupational Mobility in an American Community yr7-33, r88 (1937).

${ }^{38}$ Natalie Rogoff, Recent Trends in Occupational Mobility c. 7 (i953); Davidson and ANDERson, op. cit. supra note 37 , at 130-33; Thomas, op. cit. supra note 1, c. 9 . 
swamped the substitution and complementary effects completely. In the next part, we shall inquire whether this conclusion continues to hold.

\section{IV}

\section{Immigration, Population Density, Capital Requirements}

An influx of immigrants makes itself felt aggregatively, both directly and indirectly. Both sorts of effects were noted in part II. Here, we are concerned with what usually are the two major effects of immigration: its effect upon capital requirements, and its effect upon division of labor and the ratio of population to resources.

When a country's population grows, whether from natural increase or from net immigration, the increment in population must be provided with capital in suitable forms and amounts; otherwise, living conditions and output per worker or per capita will fall. The capital required is of three sorts: (a) industrial capital of the kinds combined with the worker in the employment in which he engages; (b) economic overhead capital, or investment in improvements in transport, building, water supply, utilities, etc., not allowed for under (a), but still essential to an increase in the volume of activity; and (c) social overhead capital, or capital utilized in residential, educational, ecclesiastical, governmental, and other facilities not provided for under (b). It may be possible, when a country is undergoing accelerated development, to skimp on forms of (b) and (c). It is essential, however, that all forms be allowed for when the longer-run impact of immigration is under consideration.

Of the two modes of estimating aggregate wealth or capital requirements, the savings-income method is most satisfactory. In a country like the United States, all wealth together approximates in value to five times the income produced in a year. Suppose now that population increases I per cent per year. Then, if 5 per cent of the national income is saved and converted into all the forms of wealth required, the wealth-population ratio will remain constant and, other things being equal, the level of per capita income will continue substantially unchanged. Five per cent, therefore, indicates the order of magnitude of the proportion of national income required to offset a I per cent per year rate of population growth. In as much as reported wealth-income ratios vary-in part because of differences in the methods of estimating employed-it may be supposed that the ratio falls within a range of $4: I$ to $6: I$, and that, therefore, the required saving rate lies between 4 and 6 per cent.

An increase in population of $x$ per cent per year is not obtained without cost, even though enough saving is done to offset the increase in question. For, the capital invested in population growth might otherwise have been invested in augmenting the wealth-population ratio and increasing productive power per head. It is probable that the capital required to support a I per cent per year rate of population growth might otherwise have been utilized to increase per capita income 
between .5 and i per cent per year. If so, the cost of a I per cent per year rate of population growth is the sacrifice of .5 -I per cent per year increase in income per head. ${ }^{39}$

The amount of capital required to equip a given rate of immigration may also be estimated by adding to the amount required, on an average, to set up an immigrant in a job, allowance for other forms of wealth required to meet the housing and other needs of himself and his dependents, and applying the resulting sum to the immigrant stream. This procedure is not very satisfactory, however, since capital invested per worker varies greatly with industry, and since it is not easy to arrive at suitable amounts for the other forms of wealth required. The savingsincome method provides the most satisfactory rule of thumb, therefore, for estimating the impact of immigration upon capital requirements and income growth, even though the composition of the immigrant stream usually differs somewhat from that of the resident population.

A country may be considered subject to increasing return when an increase in numbers-that is, in over-all population density-makes possible increase in the division of labor and the undertaking of methods more efficient that would have been possible in the absence of this increase in numbers. So long as the condition of increasing return obtains and increases in population make for increases in per capita income, a population may be said to be below income-optimum in size. Whether a population is below income-optimum size, however, depends, in part, upon the methods of production in use in that population's economy. Thus, the new methods introduced in the nineteenth century increased the magnitude of the income-optimum for many countries in which agriculture still predominated around I800. Most students would probably agree, nonetheless, that further technological improvements and related changes would be unlikely to increase the magnitude of the income-optimum further in the United States. Immigration may not, therefore, be pointed to as a force giving release to increasing return in the United States, even though it probably would still produce such effect in Canada. Accordingly, an economic case for continued immigration into the United States cannot be made if maximization of per capita income, or of its rate of growth, is the objective sought.

The economic case against the continuation of immigration is strengthened when account is taken of: (a) the fact that the population of the United States is growing from natural increase at a rate of $x .5$ per cent per year or more and is likely to continue growing at this rate for several decades or more; and (b) the fact that many of the resources of the United States are either relatively fixed or depletable in quantity. There is not a great deal more land available for putting into continuous cultivation. The limits of the water supply are being reached in some states. An increasing amount of minerals must be obtained from foreign sources, many of them

\footnotetext{
${ }^{30}$ This argument is developed in Spengler, The Population Obstacle to Economic Betterment $4 \mathrm{I}$ AM. Ecos. Rev. 343 (195I).
} 
uncertain or produced under conditions of increasing cost. In short, at the same time that the American population is growing remarkably, increasing economic entropy is shrinking the resource base of the American economy and perhaps reducing slightly its income-optimum population magnitude under present technological circumstances.

The burden of the argument presented in this part is that the aggregative effects of immigration are no longer likely to be sufficiently powerful to accelerate the rate at which per capita income advances. Accordingly, since the economic case for continuing immigration rests ultimately upon its aggregative effects, because, in the longer run, social capillarity dissolves its substitution and its complementary effects, a case cannot be made unless other sources of aggregative effect described in part II are more powerful than is commonly supposed. ${ }^{40}$

\section{V}

\section{Policy Implications}

It is not our purpose to make policy recommendations, since what is to be recommended turns on what objectives are being sought. Moreover, we are not concerned with political arguments for immigration, even though they may, at times, be persuasive. The implications of what has been said for possible courses of action may, however, be indicated.

(I) Continuation of immigration at a net rate of 250,000 per year-it has been running somewhat lower-is not likely to affect the progress of per capita income significantly, provided this rate is not continued indefinitely. This rate-about onetenth of the incremental rate of natural increase-would serve to increase the population only about .I5 or less per cent per year. It would not absorb much capital, and, even though it pressed population beyond the optimum point, it would affect income much as if returns were constant. It is not likely, of course, that immigration at this rate would long give rise to aggregative effects sufficient to increase per capita income above the level at which it otherwise would have been. Yet, as is suggested in (7) below, highly selective immigration can have salutary complementary and aggregative effects.

(2) Immigration at a rate considerably in excess of 250,000 per year would almost certainly operate to reduce the rate at which per capita income was increasing. This outcome is made all the more likely by the fact that European countries are not disposed to have the more skilled members of their labor force depart, and these, in turn, are less disposed to leave than are those in unskilled and semiskilled categories.

(3) It is not possible to translate substitution, complementary, and aggregative effects into acceptable and nonarbitrary welfare terms for the economy as a whole.

\footnotetext{
${ }^{10}$ No attempt will be made here to translate economic effects into welfare terms, because of the difficulties involved. Sce Spengler, Welfare Economics and the Problem of Overpopulation, 89 ScIENTIA 128, 166 (1954); also H. Leibenstein, A Theory of Economic-Demographic Development c. 9 (1954).
} 
In the individual case, substitution, complementary, and some aggregative effects can be assessed and added. But this cannot be done for the population as a whole, in large part because it is impossible to appraise with precision the aggregative effects associated with immigration. Furthermore, even if these effects could be expressed in income terms, they could not be translated into welfare terms unless suitable assumptions were made and accepted. For this reason, it is not easy to formulate an immigration policy designed to maximize something like welfare per head.

(4) It has been suggested that capital in the United States at present is relatively more scarce than labor, although this argument has been subjected to criticism. .1 $^{11}$ If this argument be valid, then the capital-cost of immigration is greater than has been assumed.

(5) It is said, by proponents of the view that underemployment equilibrium is typical of the American economy, that immigration, by increasing the level of investment and, hence, the level of activity in this economy, makes for fuller employment and a higher level of per capita income than would otherwise be attained. This argument is not acceptable as a basis for policy, however, since a very small amount of state intervention would produce the same effect, without increasing population density, and since immigrants are not likely at all times to find ready access to jobs in the United States. ${ }^{42}$

(6) Because the American trade union movement is so powerful, and because it exercises so much direct and indirect control over access to job opportunities in the United States, it is much more difficult for the American economy to absorb immigrants today than in the pre-Igr4 era. Because of trade-union influences, immigrants might either be denied access to jobs or be compelled to take jobs at wages in excess of marginal productivity, with the result that inflation from the cost side would be stimulated.

(7) If a certain number of immigrants are free to come to the United States and accept employment where it is offered, their coming will be favorable to all those who are engaged in complementary activities and to those who employ the services of immigrant labor, whether as employers or as the purchasers of services. Undoubtedly, there are many instances in which the resident population would experience little or no adverse substitutive effect and marked complementary and aggregative effects from limited and selective immigration. A striking example is labor which immigrates only seasonally; it benefits everyone and injures no one.

(8) It would be impossible for the United States to afford significant relief to overpopulated countries situated within or outside Europe. At most, it could accommodate enough immigrants to ease certain disequilibria in European economies. The number of immigrants the United States can absorb, at no marked cost in terms

\footnotetext{
"xee Leontief, Domestic Production and Foreign Trade: The American Capital Position Re-examined, 97 Proc. AM. PhIL. Soc'y 332 (1953); Valavanis-Vail, Leontief's Scarce Factor Paradox, 62 J. Pot. Econ. 523 (1954); Ellsworth, The Structure of American Foreign Trade: A New View Examined, 36 Rrv. Econ. \& STAT. 279 (1954).

${ }^{\star 2}$ See Spengler, Population Threatens Prosperity, 34 Harv. Bus. Rev. 85 (1956).
} 
of income, is small, far too small to approximate more than I per cent, if that, of the annual natural increment in the population of the overpopulated countries. Moreover, it would cost far more to establish a given number of immigrants industrially in the United States than in their countries of origin. Finally, and of paramount importance, emigration does not tend to bring about natality-reducing changes in the countries of emigration, ${ }^{43}$ whereas investment in the industrialization of these countries may produce such effect. In short, a given amount of American investment in the modernization of the backward economies of overpopulated countries can contribute far more to the eventual relief of population pressure than can a similar amount of investment devoted to bringing immigrants to the United States from overpopulated countries and settling them here. There it can transform both the way of life and the mode of production and thereby bring down natality.

${ }^{43}$ Ireland apparently is the only exception. See A. M. Carr-Saunders, World Populatton 64, 9092, in 4-I6 (1936); C. M. Arensberg and S. T. Kimball, Family and Community in Ireland cc. 6-8 (1940). 